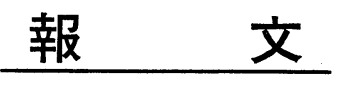

(色材, 62[7]399-403. 1989)

\title{
Effect of Silica-coating over Rutile Titania Particles on the Suppression of their Photocatalytic Activity
}

\author{
Hiroaki TAdA*, Yasuhiro SaitoH*, Kunio Miyata* and Hideo Kawahara*
}

\begin{abstract}
In order to reduce the photocatalytic activity of rutile titania particles (TOP(R)), two methods of silica-coating onto them were attempted. The amount of $\mathrm{Ag}$ photodeposited onto the particles per unit area, which was defined as the value of $z$, was calculated as an indication of their photocatalytic activities.

It was found that, when compared in the similar amount of silica-coatings, the $z$ value of TOP(R) with silica-coatings prepared by a liquid phase deposition (LPD) method was approximately 0.1 times that by the general coating method. Transmission electron micrographs and the binding energy of $\mathrm{Si}_{2 \mathrm{P}}$ electron of the coatings determined by X-ray photoelectron spectroscopy (XPS) suggest that the superior effect of the former on the suppression of the photocatalytic activity is ascribable to the characteristics of the coatings by the LPD method, which are uniformity and a dense structure.
\end{abstract}

\section{Introduction}

It is known that titania particles (TOP) cause serious degradation of paints due to the photocatalytic activity, though they are prevailing as a pigment for paint and cosmetic because of their large refractive index. Coating of TOP with oxide layers, typically one or more of silica and/or alumina, has been investigated extensively ${ }^{1 \sim 3)}$. We have previously reported that the silica-coating on the TOP, especially anatase particles (TOP(A)), by use of the LPD method ${ }^{4,5)}$ effectively decreases their photocatalytic activity against the decomposition of formic acid ${ }^{6}$.

However, the reaction was not suitable for the evalution of the photocatalytic activity of the rutile titania particles $(\operatorname{TOP}(R))$, since it was much smaller than that of TOP(A). Nishimoto et al. demonstrated that the photocatalytic activity against Ag deposition of the TOP(R) is comparable to that of the TOP(A) in aqueous silver salt solutions?).

This paper describes the effect of silica-coatings over the TOP(R) on the suppression of its photocatalytic activity in the case of photodeposition of $\mathrm{Ag}$.

\section{Experimental}

\subsection{Materials}

Titania particles and mica particles coated with rutile titania, which were further covered with silicacoatings by the general method (TOM(R)), were supplied from Teikoku Kakou Co. and used after drying at ca. $150^{\circ} \mathrm{C}$ for longer than $20 \mathrm{~h}$. The specific surface areas of them were determined to be 37.9 and $10.5 \mathrm{~m}^{2} \mathrm{~g}^{-1}$ from nitrogen adsorption at $-196^{\circ} \mathrm{C}$ by means of the BET method. All the other chemicals were reagent grade and Were used as received.

\subsection{Coating methods of silica}

The TOP(R) was coated with silica by the following two methods. One is the general method of depositing silica ${ }^{8)}$. The TOP $(R)$ was sandmilled with sodium silicate as a dispersant $\left(0.8 \% \mathrm{SiO}_{2}\right)$, and then sulphuric acid $(10 \% \mathrm{w} / \mathrm{w})$ and sodium silicate solution $\left(100 \mathrm{~g} \cdot \mathrm{dm}^{-3} \mathrm{SiO}_{2}\right)$ were added dropwise to the

昭和 63.10 .5 受理

* Central Research Laboratory Nippon Sheet Glass Co., Ltd. (1, Kaidoushita, Kounoike, Itami), 664, Japan 
diluted slurry at $90^{\circ} \mathrm{C}$ so as to maintain the $\mathrm{pH}$ at 9.4 .

The other is the LPD method patented by Nippon Sheet Glass $\mathrm{Co}^{5)}$. Three $\mathrm{ml}$ or $5 \mathrm{ml}$ of $0.5 \mathrm{~mol} \mathrm{dm}^{-}$ of $\mathrm{H}_{3} \mathrm{BO}_{3}$ was added into $\mathrm{H}_{2} \mathrm{SiF}_{6}$ aqueous solution saturated with silica gel. After the solution was stirred for $0.5 \mathrm{~h}$ at room temperature, $500 \mathrm{mg}$ of $\operatorname{TOM}(R)$ was centrifuged and washed three times with a distilled water, and then dried in air at $150^{\circ} \mathrm{C}$.

\section{3 Determination of the film thickness of silica-layer.}

2.3.1 Film thickness determined with XPS analysis

The intensity of photoelectron $\left(I i^{s}\right)$, which generates from atoms $(i)$ constituting a coating layer, can be expressed by equation (1) ${ }^{9}$.

$$
I i^{s}=I i^{\infty}\left[1-\exp \left(-f / \lambda i^{\mathrm{s}} \sin \theta\right)\right]
$$

where $f$ is the film thickness of the coating layer, $I i^{\infty}$ is the intensity of the photoelectrons generating from the atoms when the film thickness is infinite, $\lambda i$ is is the mean free path of the photoelectrons, and $\theta$ is the escaping angle of the photoelectrons. In the present case, the coating layer is assumed to be $\mathrm{SiO}_{2}$.

Equation (2) can be obtained by substituting the value of $25 \AA^{10)}$ for $i^{\text {s }}$ and the value of 7160 for $I i^{\infty}$ into the equation (1). The latter value is the intensity of the $\mathrm{Si}_{2 \mathrm{P}}$ photoelectron of the $\mathrm{SiO}_{2}$ particles measured under the following conditions ; $\mathrm{X}$-ray source was $\mathrm{MgK} \alpha(1253.6 \mathrm{eV}), \theta$ was $90^{\circ}$, and irradiation area was $5 \mathrm{~mm}$ in diameter.

$$
f(\AA)=-25 \ln [1-I i \mathrm{~s} / 7160]
$$

The mean film thickness of the silica-coatings was calculated using equation $(2)^{11}$.

The binding energies were corrected by the $\mathrm{C} 1 \mathrm{~s}$ line $(\mathrm{BE}=284.6 \mathrm{eV})$.

2.3.2 Film thickness obtained with induced coupled plasma (ICP) and BET measurement

The weight percent of the silica-coatings $\left(w_{1}\right)$ and the surface area of $\operatorname{TOM}(\mathrm{R})$ and $\operatorname{TOP}(\mathrm{R})\left(\mathrm{S} / \mathrm{m}^{2} \mathrm{~g}^{-1}\right)$ were determined by means of the ICP method and the BET method, respectively. The mean film thickness of the silica coatings on $\operatorname{TOM}(R)$ can be represented by equation (3) using the density of TOM(R) of $3.07 \mathrm{~g} \mathrm{~cm}^{-3}$.

$$
f(\AA)=32.5\left(w_{1} / S\right)+6.24
$$

Here, the value 6.24 is the film thickness of the silica-coatings of pristine TOM(R) determined by XPS.

\subsection{Evaluation of the photocatalytic activity}

Fifty $\mathrm{mg}$ of $\mathrm{TOP}(\mathrm{R})$, with or without silica-coatings, were suspended in $5 \mathrm{ml}$ of aqueous $\mathrm{AgNO}_{3}$ solution with a concentration of $5.89 \times 10^{-2} \mathrm{~mol} \mathrm{dm}^{-3}$ in a glass tube (cut off wavelength $<300 \mathrm{~nm}$ ). The suspension was purged with Ar for at least $15 \mathrm{~min}$. and sealed off with a rubber cap. The Ar-purged titania suspension was irradiated for $1 \mathrm{~h}$ under magnetic stirring at $25^{\circ} \mathrm{C}$ using a $400 \mathrm{~W}$ high-pressure mercury arc. The distance between the sample and the light source was kept at ca. $6 \mathrm{~cm}$. The centrifuged particles were washed three times with $20 \mathrm{ml}$ of distilled water and dried at $150^{\circ} \mathrm{C}$. The amount of deposited $\mathrm{Ag}$ $\left(w_{2}\right)$ was determined by means of ICP. The amount of deposited Ag per unit surface area of TOP(R) $\left(z=w_{2} / S\right)$, was used as the indication of the photocatalytic activity. The mechanism of the Ag-deposition on TOP $(R)$ has already been investigated in detail. The over-all reaction can be expressed by equation $(4)^{7)}$. This photocatalytic reaction, as well as the photodecomposition of organic compounds, is induced in terms of photocarriers $\left(e^{-}\right.$and $h^{+}$) generating in TOP(R) by the band-gap excitation. Accordingly, the adoption of the $z$-value as indication of the photocatalytic activity is considered to be valid.

$$
\mathrm{Ag}^{+}+1 / 2 \mathrm{H}_{2} \mathrm{O} \stackrel{\mathrm{TiO}_{2}, h \nu}{\longrightarrow} \mathrm{Ag}+1 / 4 \mathrm{O}_{2}+\mathrm{H}^{+}
$$

\section{Results and discussion}

\subsection{Surface analysis of $\operatorname{TOM}(\mathrm{R})$}

Figure 1 shows XPS spectra of the untreated and treated TOM(R) by use of the LPD method. The spectrum of sample (A) shows the presence of the slight amounts of $\mathrm{Sn}$ and $\mathrm{Si}$ as well as $\mathrm{Ti}, \mathrm{O}$ and $\mathrm{C}$. In the spectrum of sample (B) treated for $6 \mathrm{~h}$, the peak intensities of $\mathrm{Si}$ and $\mathrm{O}$ remarkably increase, and a new peak due to $F_{1 s}$ appears. The spectrum of sample (C) treated for $21.8 \mathrm{~h}$ exhibits that the amount of $\mathrm{Si}, \mathrm{O}$ and $\mathrm{F}$ further increase, compared with those of (B). This indicates that silica is deposited onto $T O M(R)$ by the LPD method, and that its amount increases with treatment time.

The binding energy of $\mathrm{Si}_{2 \mathrm{P}}$ electron in the $\mathrm{TOM}(\mathrm{R})$ treated with the LPD method was $103.5 \mathrm{eV}$, which agreed very closely with the value $103.4 \mathrm{eV}$ in $\mathrm{SiO}_{2}$ (quartz). 


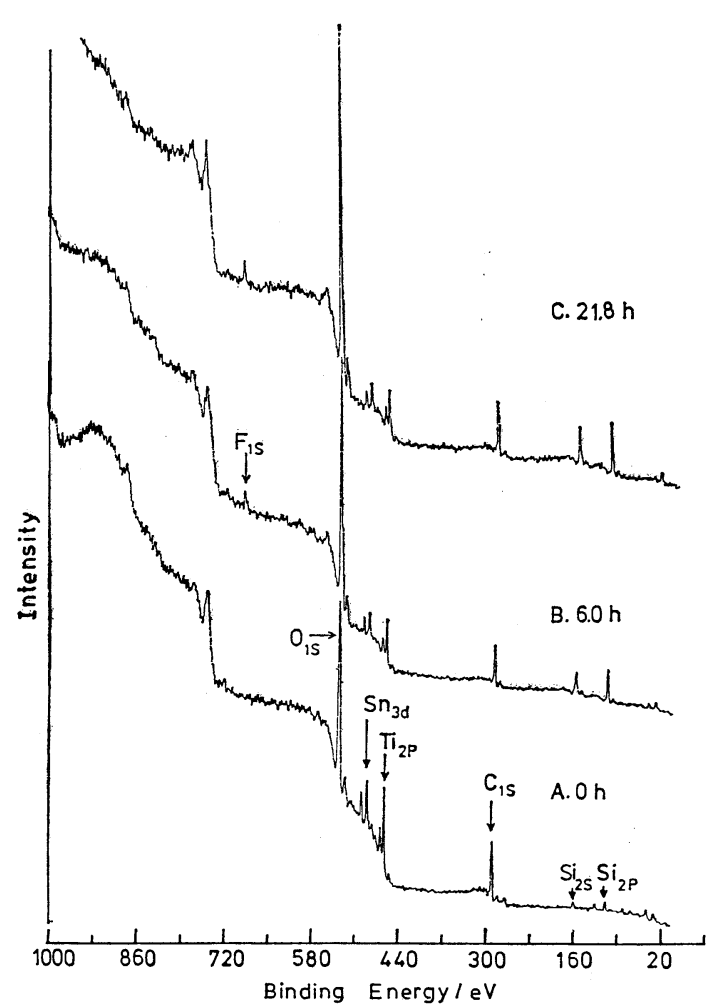

Fig. 1. XPS spectra of the untreated and treated TOM (R) by use of the LPD method: Sample. (A), pristine TOM (R); Sample (B), treatment time $(t)=6 \mathrm{~h}$; Sam- ple (C), $t=21.8 \mathrm{~h}$.

\subsection{Observation of the particles by transmission electron microscopy}

Figure 3 shows transmission electron micrographs (TEMs) of TOM(R) untreated and treated by the LPD method. The TEM of sample (A) demonstrates that the pristine TOM(R) has already been loosely

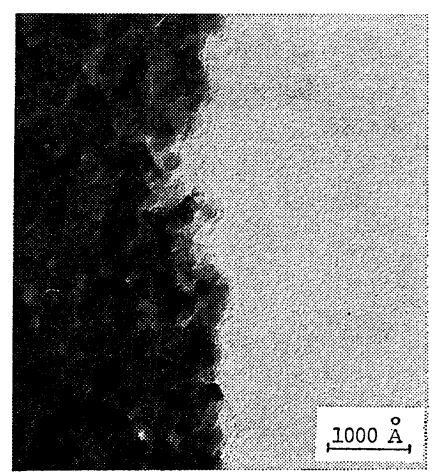

Sample (A) $\times 15 \times 10^{4}$

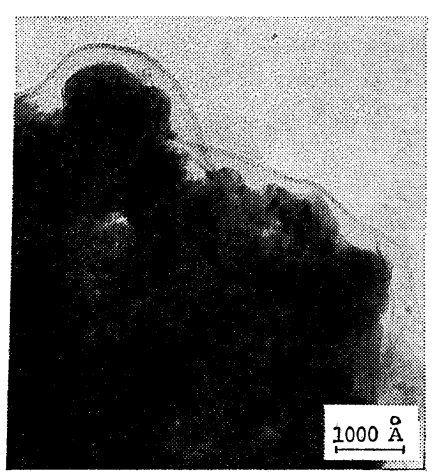

Sample (B) $\times 12 \times 10^{4}$

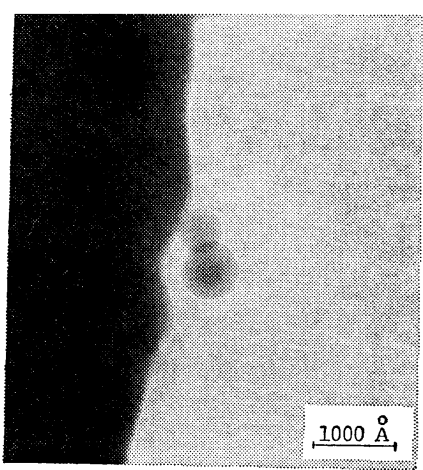

Sample (D) $\times 15 \times 10^{4}$

Fig. 3. Transmission electron micrographs of TOM $(R)$ treated and untreated by the LPD method: Sample (A), pristine TOM (R); Sample (B), treatment for $6 \mathrm{~h}$ by adding $3 \mathrm{ml}$ of $0.5 \mathrm{~mol}$ $\mathrm{dm}^{-3} \mathrm{H}_{3} \mathrm{BO}_{3}$; Sample (D), treatment for $22 \mathrm{~h}$ by adding $5 \mathrm{ml}$ of $0.5 \mathrm{~mol} \mathrm{dm}-3 \mathrm{H}_{3} \mathrm{BO}_{3}$. 
coated with silica, having the film thickness between $60 \AA$ and $200 \AA$, by the general method. The looseness of the film shown in Figure 3(A) seems to be responsible for the great difference between this film thickness and that of ca. $6 \AA$ determined by XPS, on the assumption that the silica coatings are composed of $\mathrm{SiO}_{2}$.

On the other hand, the TEM of sample (B) exhibits that the TOM(R) is uniformly covered with silica-coatings of ca. $50 \AA$ by the LPD method. The film thickness is approximately twice that determined by the XPS analysis. This suggests that the density of the silica-coatings is near to that of $\mathrm{SiO}_{2}{ }^{12)}$. However, the TEM of sample (D), which was prepared by adding $5 \mathrm{ml}$ of $\mathrm{H}_{3} \mathrm{BO}_{3}$ into the treated solution, shows that the silica-coatings are not uniform.

\subsection{The effect of the silica-coatings on the suppression of the photocatalytic activity}

In order to evaluate the photocatalytic activities of the TOP(R) with various amount of the silicacoatings; the photodeposition of $\mathrm{Ag}$ in an aqueous solution of $\mathrm{AgNO}_{3}$ was studied. Figure 4 shows dependence of the amount of photodeposited $\mathrm{Ag}$ on the the amount of the coatings. In the case of the TOM (R) treated by adding $3 \mathrm{ml}$ of $\mathrm{H}_{3} \mathrm{BO}_{3}$, the amount of deposited $\mathrm{Ag}$ abruptly decreases with increasing film thickness of the silica-coatings. When thickness is approximately $20 \AA$, the amount of deposited $\mathrm{Ag}$ decreases down to ca. 0.1 times that of the $\operatorname{TOM}(R)$. This is attributable to the decrease of the concentration of the photocarriers $\left(h^{+}\right.$or $\left.e^{-}\right)$, which lead to the photocatalytic reactions of semiconductors such as $\operatorname{TOP}(R)$, at the surface of the particles ${ }^{6}$.

In the case of the TOM(R) treated by adding $5 \mathrm{ml}$ of $\mathrm{H}_{3} \mathrm{BO}_{3}$, however, the degree of the decrease in the amount of $\mathrm{Ag}$ due to the silica-coatings is very small. This indicates that the photodeposition of $\mathrm{Ag}$ vigorously occurs at the bare sites on the surface.

From the above viewpoints, the uniform coatings of silica is found to be indispensable for the reduction of the photocatalytic activity.

3.5 Comparison of the photocatalytic activity of $T O P(R)$ coated with silica by the LPD method and by the general method

Table 1 lists the $z$ values of the TOP(R) s with the silica-coatings prepared by both the LPD method and the general method. The $z$ value of sample (B) is smaller than those of sample (A) and sample (E) by a factor of approximately 0.1. On the basis of the results described above, it is considered that the characteristics of the silicacoatings by the LPD method, i. e. the uniformity and relatively large density close to $\mathrm{SiO}_{2}$ contribute to the superior effect on the suppression of the photocatalytic activity. The latter feature guarantees that the silica-coatings by the LPD method possess a good insulating character, acting as a good barrier against the diffusion of the photocarriers towards the surface of the particles ${ }^{6}$.

\section{Conclusion}

It has been found that there are two important

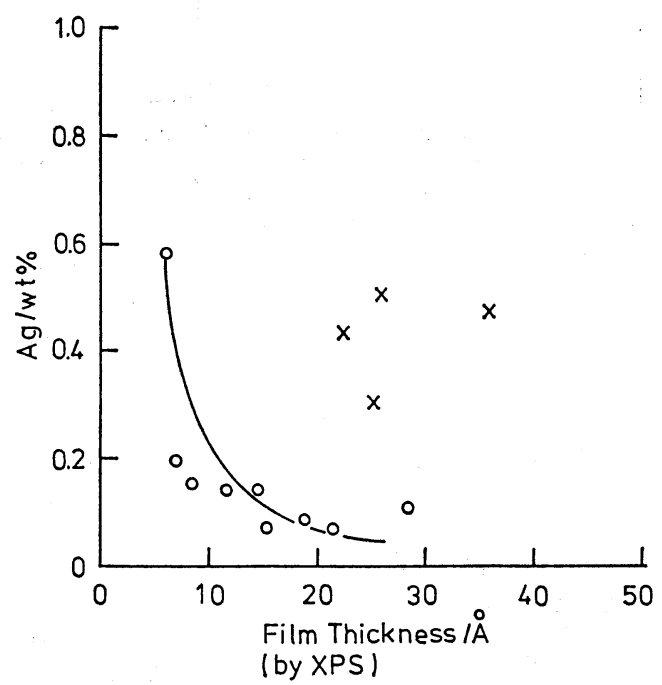

Fig. 4. Dependence of the amount of Ag photodeposited on the amount of silica-coatings : (O), treatment by adding $3 \mathrm{ml}$ of $0.5 \mathrm{~mol}$ $\mathrm{dm}^{-3} \mathrm{H}_{3} \mathrm{BO}_{3} ;(X)$, treatment by adding $5 \mathrm{ml}$ of $0.5 \mathrm{~mol} \mathrm{dm}^{-3} \mathrm{H}_{3} \mathrm{BO}_{3}$.

Table 1. $Z$ values of various rutile titania particles with silica-coatings.

\begin{tabular}{c|c|c|c|c}
\hline Sample & Method of silica-coating & $\mathrm{SiO}_{2} / \mathrm{wt} \%$ & $\mathrm{~S} / \mathrm{m}^{2} \mathrm{~g}^{-1}$ & $z / g \mathrm{~m}^{-2}$ \\
\hline $\mathrm{A}$ & General method & $-\mathrm{a})$ & 10.49 & $5.56 \times 10^{-4}$ \\
$\mathrm{~B}^{\mathrm{b})}$ & LPD method & 3.46 & 10.49 & $6.68 \times 10^{-5}$ \\
$\mathrm{E}$ & General method & $4.39 \pm 0.07$ & 41.30 & $(6.31 \pm 0.08) \times 10^{-4}$ \\
\hline
\end{tabular}

a) The film thickness of the silica-coatings was between $60 \AA$ and $200 \AA$.

b) Sample (B) was prepared dy depositing the silica coatings onto sample (A). 
requirements of the silica-coatings for the suppression of the photocatalytic activity of the TOP(R), and the coatings prepared by the LPD method satisfy them.

The first is the uniformity of the coating and the second is the dense structure.

\title{
5. Acknowledgement
}

The authors wish to express their thanks to Mr. A. Hishinuma of our laboratory for valuable comments on the experiment of the silica-coating.

\section{References}

1) W. F. Sullivan : Progr. Org. Coatings, 1, 157 (1972).

2) R. B. Cundall, B. Hulme, R. Rundham, and M.S.Salim : J. Oil Col. Chem. Assoc., 61, 351 (1978).

3) R.E. Day, and T. A.Egerton:Colloids and Surfaces, 23, 137 (1987).

4) H. Nagayama, H. Honds, and H. Kawahara: Amer. Ceram. Soc., 87 th Annual Meeting (1985).

5) H. Nagayama : Japan Patent 58-161944.

6) H. Tada, K. Miyata, H. Yoshida and H. Kawahara: J. Japan Soc. Colour Material, 61, 665 (1988).

7) S. Nishimoto, B. Ohtani, H. Kajiwara, and T. Kagiya: J. Chem. Soc., Faraday Trans. 1, 79, 2685 (1983).

8) R. K. Iler : U.S. Patent 2, 885, 366 (1959).

9) T. A.Egerton, G.D.Parfitt, Y. Kng and J.P.Wightman : Colloids and Surfaces, 7, 311 (1983).

10) R. Flitsch, and S. I. Raider:J. Vac. Sci. Technol., 12, 305 (1975).

11) Y. Taru, K. Tanaka, M. Yokoyama and H. Honda: J. Japan Soc. Colour Material, 59, 315 (1986).

12) H. Nagayama, H. Honda and H. Kawahara : J. Electrochem. Soc., 135, 2013 (1988).

\section{ルチル型チタニア微粒子の光触媒活性におよぼす シリカ被覆処理の影響}

\author{
多田弘明*・斉藤靖弘*・宮田邦夫* ・河原秀夫* \\ * 日本板硝子(株)中央研究所・兵庫県伊丹市鴻池街道下 1 番 (广664)
}

要 旨

ルチル形チタニア微粒子 (TOP $(R))$ の光触媒活性を低下させることを目的として，2 種類の方法でシリカ被 覆を試みた。1つは, ケイ酸ナトリウム水溶液からの析出反応を用いる従来法であり, 他の 1 つは, ケイフッ化 水素酸水溶液からの析出反応を利用した液相成膜 (LPD) 法である。TOP $(R)$ ) の光触媒活性の評価には, 硝酸 銀を含む懸濁液への光照射により TOP $(R)$ 上に析出した単位表面積当りの銀の重量（ $\boldsymbol{z}$ 值）を用いた。

その結果， LPD 法でシリカ被覆処理した TOP $(R)$ の $z$ 值は，従来法で処理したものの約 $1 / 10$ であること が明らかとなった。

透過型電子顕微鏡写真とX線光電子分光法による分析結果は, 従来法よりも LPD 法による方がシリカ被覆膜 は均一であり，また，ち密な構造をしていることを示唆しており，このために優れた光触媒活性抑制効果を発現 するものと考えられた。 